\author{
MACIEJ ZIEMIAŃSKI ${ }^{1,2}$, AGATA KLIMCZAK ${ }^{3}$
}

${ }^{1}$ Białowieska Stacja Geobotaniczna Wydziału Biologii Uniwersytetu Warszawskiego Sportowa 19, 17-230 Białowieża

${ }^{2}$ Zakład Ekologii Roślin i Ochrony Środowiska Wydziału Biologii Uniwersytetu Warszawskiego Centrum Nauk Biologiczno-Chemicznych Uniwersytetu Warszawskiego

Żwirki i Wigury 101, 02-089 Warszawa

${ }^{3} I$ Wydzial Lekarski

Warszawski Uniwersytet Medyczny

Żwirki i Wigury 61, 02-091 Warszawa

E-mail:m.a.ziemianski@biol.uw.edu.pl

klimczak.agatha@gmail.com

\title{
HOTELE DLA OWADÓW - DOBRA PRAKTYKA CZY WIELKA POMYŁKA?
}

\section{ZALEŻNOŚCI LUDZI I OWADÓW ZAPYLAJĄCYCH}

Oddziaływanie człowieka na środowisko naturalne, w tym na owady zapylajace, jest przedmiotem badań naukowców od wielu lat. Ma ono zarówno charakter bezpośredni, jak i pośredni. Ludzie swoimi działaniami wpływają zarówno pozytywnie, jak i negatywnie na środowisko. Każdy $z$ nas poprzez swoje działania modyfikuje otaczajaca przestrzeń, konsumując zasoby naturalne i korzystając $z$ osiągnięć cywilizacji. Użytkowanie infrastruktury, wzrost urbanizacji, produkcja rolna i przemysłowa wielokierunkowo zmieniaja nasza planetę. Postępująca chemizacja w rolnictwie jest źródłem poważnych zagrożeń dla istnienia wielu gatunków oraz kondycji poszczególnych populacji owadów zapylajacych. W wyniku stosowania środków chemicznych często dochodzi do wypierania rodzimych gatunków owadów $z$ optymalnego dla nich terenu (WILlMER 2011, SENAPATHI i współaut. 2016).

Produkcja rolna, aby sprostać potrzebom rosnącej populacji, musi zmieniać się przynajmniej w jednym $z$ poniższych wymiarów: podlegać ekspansji terytorialnej, zwiększać wydajność poprzez stosowanie lepszych odmian roślin uprawnych lub zwiększenie udziału środków ochrony roślin. Szczególnie środki ochrony, stosowane $\mathrm{w}$ połaczeniu $\mathrm{Z}$ wielkopowierzchniowymi monokulturami rol- nymi, wpływaja negatywnie na liczne bezkręgowce. Wpływ ten ujawnia się poprzez skażenie pokarmu, roślin, kwiatów, zniszczenie miejsc schronienia i reprodukcji oraz zaburzenia w sieciach interakcji międzygatunkowych. Rolnictwo, modyfikujac krajobraz, może prowadzić do powstawania obszarów pustyń pokarmowych i pułapek dla zwierząt o ograniczonych zdolnościach do przemieszczania się, np. niewielkich owadów. Takie odosobnione rejony, $z$ których zwierzętom nie sposób się skutecznie wydostać, w dłuższej perspektywie powoduja zubożenie puli genetycznej. Garnitur genów występujacych tam populacji organizmów maleje na skutek chowu wsobnego i postępujacego zaciagania tzw. długu ekstynkcji (ang. extinction dept). Dodatkowo, zwiększa się podatność na inwazje biologiczne destabilizujace interakcje lokalnych sieci zależności. Dzieje się tak w wyniku zwiększania powierzchni pojedynczych gospodarstw, zaniku obszarów nieużytków, takich jak miedze, zadrzewienia i rowy śródpolne. A właśnie takie miejsca dostarczaja ostoi oraz pokarmu dla owadów. Potwierdzaja to wyniki prezentowane dla obszarów rolnych Holandii i Wielkiej Brytanii, gdzie autorzy stwierdzili ujemna korelację wielkości pól uprawnych i liczebności zapylaczy (BIESMEIJER i współaut. 2006).

Kolejnym, bardzo ważnym zagrożeniem dla funkcjonowania ekosystemów jest postępujaca fragmentacja środowiska natural- 
nego, która także jest jednym $\mathrm{z}$ czynników powodujacych spadek różnorodności biologicznej organizmów. Najbardziej wrażliwe na opisany mechanizm spośród pszczołowatych sa pszczoly samotnice (AIzEN i GALETTO 2002, STEFFAN-DEWENTER i współaut. 2006, TAKI I KeVAn 2007). Proces fragmentacji może zachodzić $\mathrm{w}$ różnym tempie, na odmienną skalę $i \mathrm{z}$ różna intensywnościa, może mieć także różnorodna genezę. Szczególnym przypadkiem prowadzącym do fragmentacji jest dynamiczny wzrost urbanizacji. Poprzez niekiedy ekstremalnie szybkie tempo przekształceń miasta, elementy środowiska naturalnego nie są $\mathrm{w}$ stanie zaadaptować się do zmieniających się warunków. Zjawisko urbanizacji dotyczy wszystkich kontynentów (z wyłączeniem Antarktydy). Dynamika rozwoju miast jest różnorodna, zależnie od rejonu geograficznego, uwarunkowań przestrzennych i historii danego obszaru, lecz jej trend $\mathrm{w}$ skali globalnej jest stały. Prognozy przedstawione przez GRIMMA i współaut. (2008) wskazuja, że średni poziom urbanizacji na świecie w 2030 r. ma osiagnać $60 \%$. Co więcej, obecnie na terenie Europy nawet do $80 \%$ ludności mieszka w miastach.

Równolegle $z$ rozwojem miast następuje rozwój sieci komunikacyjnej, która zapewnia swobodę przepływu ludzi, towarów i usług dla rozwijających się miast, co także wpływa na otaczajace środowisko. Wiaże się to bezsprzecznie $\mathrm{z}$ koniecznością zaspokojenia potrzeb mieszkańców, co można zobrazować poprzez oszacowanie tzw. śladu ekologicznego (ang. ecological footprint), mierzonego $\mathrm{w}$ hektarach powierzchni potrzebnej do zaspokojenia potrzeb pojedynczego człowieka. Tak rozumiana antropopresja powoduje zaburzenia w lokalnych ekosystemach. Przyjmując postępujący wzrost jej siły, możemy prognozować, że skład gatunkowy i relacje między taksonami będa coraz silnej modyfikowane przez działania ludzi. W przyszłości może to doprowadzić do całkowitej utraty ekosystemów o cechach naturalnych (GoDDARD i współaut. 2010). Równie w obrębie miast proces przekształcania siedlisk może postępować $z$ różną szybkościa $i$ intensywnością, zależnie od przyjętego planu zagospodarowania terenu, polityki zarządców i liczby napływających mieszkańców. Organizmy, które żyja w sąsiedztwie przekształcanych obszarów, mają ograniczone możliwości korzystania $z$ powierzchni biologicznie czynnych i wkraczania na tereny zmienione antropogenicznie przez systematycznie rozrastająca się zabudowę. Regres populacji roślin występujących w bliskim sąsiedztwie miasta może mieć swoje przyczyny nie tylko $\mathrm{w}$ bezpośrednim oddziaływaniu ludzi na osobniki, ale także w sposób pośredni, po- przez modyfikacje zespołów zapylaczy odwiedzajacych te rośliny. Jest to bardzo istotne dla istnienia niektórych populacji, gdyż w wyniku zahamowania rozmnażania generatywnego może dojść do zmniejszenia ich liczebności, a w najgroźniejszym przypadku do całkowitej ekstynkcji. Ważna, $\mathrm{z}$ punktu widzenia reprodukcji roślin, jest także zdolność dyspersji nasion. Wielu gatunkom do rozprzestrzeniania służą zwierzęta, których brak może mieć również negatywne skutki dla istnienia i kondycji populacji (WILLMER 2011). Ponadto, wzrost udziału powierzchni nieprzepuszczalnych, będących nieprzyjaznymi siedliskami $\mathrm{w}$ miastach, stoi $\mathrm{w}$ sprzeczności z powszechną dziś koncepcja zielonych i przyjaznych miast dla ich mieszkańców (FORTEL i współaut. 2014). Z drugiej strony, miasta stanowia swoiste wrota dla inwazji gatunków obcych, które docierają do nich na wiele sposobów. Mo ze to być nieświadoma (tzw. zawlekanie) lub celowa introdukcja przez ludzi. Takie wzbogacenie ekosystemów i stworzenie mozaiki heterogennych mikrosiedlisk może przynosić pewne korzyści dla owadów zapylajacych. Dzięki wysokiemu bogactwu organizmów na stosunkowo niewielkich terenach (istnieniu tzw. „hotspotów”) nawet niewielkie tereny zielone $\mathrm{w}$ miastach moga stać się bardzo ważne dla ochrony entomofauny (HERNANDEZ i współaut. 2009). Moga być to zarówno parki miejskie, skwery, jak i np. cmentarze czy przydomowe ogrody (SENAPATHI i współaut. 2016). Nie jest wykluczone, że w efekcie miejska przestrzeń może okazać się bardziej atrakcyjna od obszarów pozamiejskich (uboższych w gatunki) (BANASZAK-CIBICKA 2015). Spełnienie kryteriów wyższej atrakcyjności dla owadów ma miejsce, gdy zaspokajane sa ich różnorodne potrzeby. Głównymi wymaganiami jest dostęp do obfitego i różnorodnego pokarmu (zarówno $\mathrm{w}$ czasie, jak $\mathrm{i} \mathrm{w}$ przestrzeni) oraz wody. Pokarmem sa pyłek i nektar dostarczane przez rośliny kwiatowe. Kolejnym ważnym wymaganiem jest dostęp do schronień i miejsc lęgowych, których niedobór w mieście moga kompensować hotele dla owadów. Rozwój miast wpływa więc w różny sposób na różnorodność biologiczną i interakcje pomiędzy gatunkami w ekosystemach (CHEPTOU i AVENDAÑO 2006).

\section{ZJAWISKO ZAPYLANIA I KRYZYS ZAPYLEN}

Proces zapylania jest obiektem zainteresowania badaczy od czasów Karola Darwina. Jednak dopiero w latach 50. XX w. rozpoczęto analizy sposobów przeciwdziałania negatywnym skutkom wpływu człowieka na ten proces. Od 1970 r. nastapił dynamiczny 
wzrost liczby publikacji dotyczących tej tematyki.

Istnienie roślin kwiatowych zależy nie tylko od efektywnego przeprowadzania procesu fotosyntezy, konkurowania o przestrzeń i zasoby, ale także od produkcji nasion, $z$ których po wykiełkowaniu wyrastaja kolejne generacje osobników. Powstawanie nasion $u$ zoogamicznych roślin kwiatowych, czyli takich, które zapylane sa $z$ udziałem zwierząt, jest wynikiem milionów lat ewolucji i pojawiło się u bardzo wielu gatunków. Poziom specjalizacji w relacji roślina-zapylacz różni się pomiędzy poszczególnymi gatunkami. Jest to wynikiem wielu składowych biologii tych gatunków oraz uwarunkowania historycznego i geograficznego. Na Ziemi znajduja się rejony, w których udział takich wasskich specjalizacji w stosunku do ogółu jest wyższy niż w innych. Przykładem jest Madagaskar, gdzie ze względu na izolację geograficzna od kontynentu afrykańskiego ewolucja przebiegała innymi torami, prowadzac do powstania bogatszych ekosystemów. Według szacunków OLLERTONA i współaut. (2011), ponad $87 \%$ roślin kwiatowych jest zapylanych zoogamicznie.

Jako wektory ziaren pyłku służą zarówno wiatr, woda, jaki i zwierzęta odwiedzające kwiaty. Ryzyko ograniczenia reprodukcji może wynikać $z$ ograniczeń, jakim podlegaja te zjawiska, substancje i organizmy.

Celem odwiedzin zapylaczy jest uzyskanie wymiernych korzyści dla samych siebie, a nie przeniesienie pyłku pomiędzy strukturami generatywnymi roślin. Powodami prowadzacymi do odwiedzin sa atraktanty, które służą zoogamicznym roślinom do przywabienia gości kwiatowych. Rośliny moga w różny sposób zwiększać swoja atrakcyjność, np. poprzez wytwarzanie barwnych kwiatów, często skupionych w kwiatostanach. Ponadto, aby wzmocnić ten efekt, rośliny często wystepuja w zwartych skupiskach (MAKINO i współaut. 2007, WILLMER 2011, JĘDRZEJEWSKA-SZMEK i ZYCH 2013). Wysiłek energetyczny roślin (poza oszustami pokarmowymi np. storczykami) rozszerza się na wytworzenie nagród kwiatowych, które przeznaczone sa dla potencjalnych zapylaczy. Sa nimi: nektar o dużej zawartości cukrów i wody, pyłek bogaty w białka, ciałka jadalne oraz inne substancje interesujace $z$ punktu widzenia zwierząt (WILLMER 2011). Rośliny, w zamian za zainwestowana materię i energię, w wyniku wizyty zapylaczy uzyskuja niezbędny dla reprodukcji transfer pyłku. Usługi świadczone nawzajem przez przedstawicieli dwóch królestw, roślin i zwierząt, są najczęściej przejawem mutualizmu (OLLERTON i wspó1aut. 2011, WILlMER 2011). Transfer pyłku $z$ udziałem owadów jest bardzo powszech- ny, jednak odbywa się $z$ minimalna skutecznościa, oscylujaca około 1\%. Mimo tak niskiej efektywności, w wielu ekosystemach dominuje zapylanie przez zwierzęta (RENNER i współaut.1998), gdyż rośliny wynagradzając gości kwiatowych, mają pośrednio wpływ na ich zachowanie. Oprócz owadów stanowiących główną grupę zapylaczy, transferu pyłku dokonuja ptaki i ssaki, wśród nich nietoperze. Konsekwencja opierania reprodukcji na interakcjach ze zwierzętami jest przyspieszenie tempa specjacji roślin. Wynika to $z$ obustronnej specjalizacji gatunków (KAY i współaut. 2006). Mimo powszechności zoogamii, często $\mathrm{w}$ naturalnych populacjach obserwuje się zjawisko limitacji pyłkiem (ang. pollen limitation). Jest ono stanem polegajacym na zdeponowaniu niewystarczającej ilości zdolnego do kiełkowania pyłku na znamieniu słupka, potrzebnej do wyprodukowania maksymalnej możliwej liczby nasion. W rezultacie prowadzi to do redukcji dostosowania (ang. fitness) osobnika (KNIGHT i współaut. 2005). Przyczyna takiego zjawiska jest między innymi brak lub niedostateczna liczba realizowanych odwiedzin gości kwiatowych. Ponadto, zwierzęta które odwiedzaja kwiaty, moga być morfologicznie niedostosowane do transferu pyłku, moga także odwiedzać kwiaty tylko podczas jednej $z$ faz płciowych kwitnienia i w konsekwencji nie dokonywać transferu pyłku na znamiona. Alternatywna przyczyna istnienia zjawiska limitacji pyłkiem jest deponowanie na znamionach słupków roślin samosterylnych ich własnego pyłku. Nie ma on zdolności do kiełkowania i tworzenia łagiewki pyłkowej i powoduje zatykanie znamion (ang. stigma clogging) (WILLMER 2011). W obliczu tak wielu zagrożeń utrzymywanie się procesu zapylania na stabilnym poziomie, zapewniajacym zróżnicowanie genetyczne populacji, może być dobrym wskaźnikiem optymalnego stanu zachowania ekosystemów (WILLMER 2011).

Globalny kryzys zapyleń jest zjawiskiem, z którym musi zmierzyć się dzisiejszy świat, gdyż jego reperkusje moga być dotkliwe i negatywnie oddziaływać na cała światowa populację ludzi (POTTs i współaut. 2010). Doniesienia dotyczace kryzysu pojawiaja się w literaturze już od ponad trzydziestu lat, przy czym badacze wskazuja, że zagadnienie to jest niedostatecznie rozpoznane i wymaga dalszych badań (WILLMER 2011). Nikt jednak nie ma wątpliwości, że istnienie owadów jest kluczowe dla trwania ekosystemów w takich ramach, jakie znamy obecnie. Niepokojacce jest jednak to, że nadal niewiele wiemy o funkcjonowaniu wielu grup zapylaczy. Tym trudniej jest nam oszacować negatywny wpływ na nie, bez wiedzy stanowiącej bazę (punkt referencyjny). 
Mówiąc o kryzysie zapyleń należy przeanalizować dotychczasowy stan wiedzy i określić, czy owady zapylajace podlegaja identycznym zagrożeniom, czy też każda $\mathrm{z}$ grup tych bezkręgowców może odpowiadać w inny sposób na zagrożenia wynikające $z$ tego zjawiska. Przyjmując podsumowania dokonane przez WiLLMERA (2011) należy zaznaczyć, że rolnictwo opiera się w dużym stopniu na usługach pszczół będacych jedna $z$ najistotniejszych grup zapylaczy. $Z$ punktu widzenia gospodarczego i ekonomicznego, dotychczas największe nakłady i w konsekwencji uwaga badaczy były skierowane na pszczołe miodną (Apis mellifera L.), najbliższą człowiekowi $\mathrm{z}$ wielu względów. W ostatnich latach bardzo niepokojace i szokujace $\mathrm{w}$ swojej skali jest zjawisko masowego i ekstremalnie szybkiego wymierania całych rodzin pszczelich (rojów) (ang. colony collapse disorder, CCD) (Evans i współaut. 2009). Dla stabilnej produkcji rolnej ten gatunek jest najistotniejszy, a problemy wynikajace $z$ jego masowego wymierania niosa ze soba straty liczone w miliardach dolarów amerykańskich (WILLIAMS i współaut. 2010). W efekcie, rolnicy oraz osoby odpowiedzialne za środowisko, coraz częściej zwracają uwagę na dotychczas zaniedbywane alternatywne gatunki owadów zapylających należące do nadrodziny Apoidea. Wśród nich aż $90 \%$ stanowia tzw. pszczoły samotne (WILLMER 2011), z których część może być beneficjentami sztucznych miejsc do gniazdowania, czyli tzw. hoteli dla owadów. Jednym $z$ najczęściej sztucznie hodowanych gatunków pszczół samotnych jest powszechnie wykorzystywana $w$ rolnictwie murarka ogrodowa (Osmia rufa L.). Co zastanawiające, jej efektywność w zapylaniu (przeliczona na osobnika, w stosunku do pszczoły miodnej) jest zdecydowanie większa, natomiast gatunek ten nie dostarcza miodu (MiCHENER 2000). Nie mamy jednak dostatecznej informacji o alternatywnych dla pszczoły miodnej gatunkach zapylaczy, które mogłyby przejać tak duży ciężar odpowiedzialności za produkcję żywności. Uprzednie i trwajace obecnie badania próbuja przybliżyć to zagadnienie, lecz nadal nie mamy pełnej wiedzy na ten temat. Dotychczas wiadomo, że współwystępowanie pszczoły miodnej i innych gatunków błonkówek, np. murarki z gatunku Osmia lignaria, pozytywnie wpływa na efektywność realizowania przez owady usług ekosystemowych w sadach. Ruch owadôw między kwiatami roślin był wzmożony, gdy różne gatunki współwystępowały $\mathrm{w}$ środowisku. Zwiększyła się także produkcja owoców w analizowanych sadach (BRITTAIN i współaut. 2013). Analogicznie, WILLMER (2011) stwierdził pozytywny wpływ trzmieli na efektywność zapylania przez pszczoły miodne. Istotnym byłoby opracowanie skutecznych i latwych do zastosowania sposobów ochrony czynnej populacji owadów zapylajacych. Dlatego też akcje dotyczace ochrony zarówno rodzin pszczelich, jaki i trzmieli oraz pszczół samotnic (zarówno gatunków pospolitych jak i rzadkich, chronionych, np. w wykazach oraz umieszczonych na Czerwonej Liście) sa cenne dla ochrony środowiska i różnorodności biologicznej.

\section{CZYM JEST HOTEL DLA OWADÓW?}

Wedle koncepcji projektantów, hotele dla owadów maja zapewnić schronienie i miejsce lęgowe licznym gatunkom bezkręgowców. W zależności od konstrukcji i zastosowanych materiałów oraz umieszczenia $\mathrm{w}$ przestrzeni maja być użytkowane np. przez pszczoły samotnice, trzmiele, motyle, skorki, biedronki i inne grupy owadów. Urządzenia takie przedstawiane sa pod różnymi nazwami, często nieprecyzyjnymi. Określenie „hotele dla owadów” lub też „domek dla owadów”, z punktu widzenia entomologa nie sa $\mathrm{w}$ pełni poprawne, lecz realnie, dla tych obiektów małej architektury ogrodowej nie ma dobrych nazw alternatywnych.

W celu zapylania upraw i sadów specjalnie prowadzi się hodowlę różnych gatunków owadów. Poza pszczołami miodnymi, w pasiekach rozmnażane sa trzmiele i pszczoły samotnice. Trzmiele preferowane sa do wykorzystywania $\mathrm{w}$ zapylaniu upraw $\mathrm{w}$ szklarniach i pod innymi osłonami. Gatunkiem trzmiela, który jest sprzedawany na rynku jest trzmiel ziemny (Bombus terrestris), zaś spośród pszczól samotnic, hodowane i wykorzystywane sa np. porobnica włochatka (Anthophora plumipes), nożycówka pospolita (Chelostoma florisomne), wałczotka dwuguzka (Heriades truncorum) i miesierka lucernówka (Megachile rotundata). W latach 90. $\mathrm{XX}$ w. proponowano używać nazw „miesiernik" i „megachilnik” od grup owadów, którym dedykowano takie konstrukcje ustawiane $\mathrm{w}$ obrębie upraw sadowniczych (BANASZAK 1993). Najpełniej rolę konstrukcji oddaje nazwa „sztuczne miejsca gniazdowe”. Z założenia, sama nazwa sugeruje, że urzadzenia zawieraja pewną różnorodność mikrosiedlisk zawartych w konstrukcjach. W ogólnym zarysie konstrukcje składaja się $z$ zadaszonej ramy wypełnionej kilkoma różnymi rodzajami materiałów, takimi jak pocięta trzcina, pędy bambusa, różnych gatunków rdestowców, podziurawione (nawiercone) drewno, dziurawe cegły i potłuczone donice, ścianki $z$ gliny czy porcje suchych liści oraz szyszek, jednakże nie jest to reguła. Stosowane drewno należy do różnych gatunków: olchy, sosny, robinii akacjowej, lipy czy brzozy. „Domek dla 
owadów" może być w zasadzie dowolną konstrukcja $z$ daszkiem, przypominajaca domki dla ptaków lub drobnych ssaków, takich jak nietoperze i wiewiórki. Prawdopodobnie używanie tej nazwy wiazało się $z$ podobieństwem kształtu i gabarytów do budek lęgowych, częstych w przestrzeni miejskiej. Nazwy stosowane powszechnie dla takich obiektów odzwierciedlają możliwości użytkowania przez wiele grup owadów. Beneficjentami hoteli dla owadów jest tylko część fauny bezkręowców, które w Polsce licza ponad 30 tysięcy gatunków. Żądłówki, które mają być głównymi "lokatorami” tych konstrukcji, stanowia zaledwie kilka procent ogółu. Forma obiektu zależy głównie od upodobań projektantów lub wykonawców, aczkolwiek, aby konstrukcja spełniała prawidłowo swoje funkcje, muszą zostać zrealizowane pewne podstawowe założenia. Sa to parametry dotyczace minimalnej głębokości i średnicy otworów, kąta ich pochylenia względem frontu konstrukcji determinującego wilgotność w ich wnętrzu. Ważne sa także: jakość wykonania i zastosowane materiały, które musza być pozbawione wilgoci, poprzez np. suszenie przed obróbka (BANASZAK 1993). Gabaryty zrealizowanych hoteli mogą znaczaco się różnić; największe sztuczne miejsca gniazdowe osiagaja rozmiary liczone w metrach, zaś najmniejsze moga ograniczać się do kilkunastu centymetrów dla ich największego wymiaru. Wielkość obiektów często koresponduje $z$ ich jakościa, rozumiana jako liczba potencjalnych dostepnych nisz do zasiedlenia. Jednymi $z$ najlepiej opisanych sztucznych miejsc leggowych dla zapylaczy były te, które tworzono dla pszczół, komercyjnie wykorzystywanych w produkcji rolnej i sadowniczej. Takim gatunkiem jest murarka ogrodowa, której biologię poznano szerzej. Jest to jednopokoleniowy gatunek, żyjacy samotnie, jednak w odpowiednich warunkach może tworzyć kolonie o dużej liczebności (SzEFER 2012). Hodowla tego gatunku, poza pożytkiem ekonomicznym (BILIŃSKI i TEPER 2004), ma również często aspekt hobbistyczny. Murarki często jako miejsca gniazdowania wybieraja istniejacce szczeliny i otwory, np. suche łodygi roślin, pęknięcia w drewnie, zaprawie i pustakach. Samice odpowiadaja za budowę gniazd o charakterze liniowym. $\mathrm{Na}$ gniazda składaja się ułożone kolejno w linii komórki, zwane także kompartmentami, w liczbie zwykle od 2 do 15 sztuk. Komory przedzielane sa za pomoca przegród $z$ błota zmieszanego ze śliną samic. Do komórek budowanych przez owady składane sa jaja oraz dostarczany jest pokarm. Wedle doświadczeń hodowców, gniazdo powinno mieć średnicę od 5 do $8 \mathrm{~mm}$, zaś głębokość w przedziale 10 do $15 \mathrm{~cm}$. Rekomendowane jest także to, aby przestrzenie do gniazdowania były zamknięte od tyłu litą ściana w postaci np. naturalnego kolanka wewnatrz łodygi trawy lub litego kawałka drewna (BANASZAK 1993, SzEFER 2012). Prowadzone badania nad odpowiedzią owadów (pszczół samotnic) na atrakcyjność sztucznych miejsc gniazdowych dowiodły, że najlepsze wyniki hodowli uzyskiwano przy wykorzystaniu następujacych materiałów: pustych łodyg trzciny pospolitej (Phragmites australis L.), papierowych i kartonowych rurek oraz drewnianych bloków $Z$ nawierconymi otworami (SzEFER 2012). Różnice w wielkości średnicy otworów wynikaja z rozbieżnych parametrów wielkości samic owadów. Długość gniazd dla różnych żądłówek może dochodzić do $25 \mathrm{~cm}$. W przypadku owadów społecznych, takich jak trzmiele, proponowane sa inne rozwiazania, np. pozostawianie nagromadzenia liści i gałęzi w zacisznych miejscach terenów zielonych lub przygotowanie specjalnych kopców z kamieni, służących zarówno do zimowania samic, jak i gniazdowania. Poza takimi, najbardziej zbliżonymi do naturalnych, miejscami gniazdowania, istnieja specjalne skrzynki $z$ otworem przewidziane dla rodzin trzmieli. Konstrukcje dla skorków to $z$ kolei podwieszone otworem do dołu doniczki lub miski wypełnione mieszanina słomy i gliny. Miejsca przewidziane dla motyli to konstrukcje drewniane $z$ pionowymi, eliptycznymi otworami/wejściami o dużej długości, służące za schronienie tej grupie organizmów. W przypadku hoteli przeznaczonych dla różnorodnych grup, wypełnienie i wynikajace $z$ niego nisze sa zdywersyfikowane, a gabaryty konstrukcji wzrastają. Często takie duże twory przypominaja swoimi kształtami zmodyfikowane budy dla psów lub bardziej finezyjne w kształcie plastry miodu (wielokaty foremne). Najbardziej okazałe konstrukcje przyjmuja niekiedy niecodzienne formy, takie jak choćby przestrzenne odwzorowanie napisu „ZOO”, znajdujące się w ogrodzie zoologicznym w Płocku, czy też dziewięciometrowej wysokości hotel dla owadów, będacy budowlą prezentowana podczas Chelsea Flower Show w Anglii w 2011 r. Ta konstrukcja była najwyższa w historii wystaw Chelsea, stanowiąc część ogrodu B\&Q, nagrodzonego złotym medalem. Obiekt ten zbudowały dzieci w ramach programu edukacyjnego na rzecz zachowania różnorodności biologicznej, z użyciem odpadów, takich jak stare ksiażki, zabawki, papier, siano i rolki papieru toaletowego. Dowodzi to, że spektrum zastosowanych materiałów może być jeszcze szersze niż opisane powyżej, natomiast nietrwałe produkty sa często pomijane ze względu na szybka utratę pożądanej funkcji i estetyki. Odporne na warunki atmosferyczne, a w konsekwencji warunkujące długa trwałość, są głównie konstrukcje drewniane wykonane 
z uprzednio przygotowanych (wysuszonych) i przyciętych bali i belek. Nawiercane otwory nie powinny się, co do zasady, ze soba krzyżować wewnątrz bloku. W drewnianym hotelu ważne jest zachowanie możliwie niewielkich odległości pomiędzy poszczególnymi otworami, gdyż wtedy wejścia do gniazd sa szybciej odszukiwane przez pszczoły zakładające nowe gniazda (SzEFER 2012). Jeżeli natomiast celem obiektu jest pozyskanie kokonów, np. murarki ogrodowej, polecane sa rurki kartonowe lub papierowe, ewentualnie trzcinowe, gdyż znaczaco łatwiejsze jest pozyskiwanie $z$ ich wnętrz kokonów w celu hodowli i przechowywania. Duże nagromadzenia otworów przyciagają $z$ jednej strony liczne samice pszczół samotnic, zaś $z$ drugiej strony, zwiększaja ryzyko zwabienia pasożytów gniazdowych (kleptopasożytów) oraz drapieżników, takich jak ptaki (np. dzięcioły).

Dlatego też $w$ celu ochrony owadów mieszkajacych wewnatrz hoteli stosuje się proste zabezpieczenia, wykonane $z$ plastikowych i metalowych siatek $z$ gestymi oczkami, które zapobiegaja zniszczeniu wypełnienia konstrukcji przez ptaki. Poruszajac temat estetyki należy pamiętać, że sztuczne miejsca gniazdowe dla owadów, poza swoim czysto praktycznym wymiarem, maja też pełnić rolę uzupełnienia krajobrazu ogrodów i parków miejskich, wtapiając się w otoczenie lub wręcz przeciwnie, wyraźnie odcinając, przy podkreśleniu swoich walorów estetycznych. $Z$ naukowego punktu widzenia, estetyka nie odgrywa kluczowej roli w zasiedlaniu konstrukcji przez owady, jednak sugeruje się, że pomalowanie powierzchni hotelu we wzory geometryczne ułatwia żądłówkom identyfikacje swoich gniazd (BANASZAK 1993).

Preferencje zasiedlania oferowanego w konstrukcjach materiału gniazdowego przez pszczoły samotnice w Polsce były zróżnicowane i wynosiły od około $16 \%$ stwierdzonych zasiedleń w dostępnych niszach w drewnie, do około $2 \%$ dla przestrzeni w przygotowanych pędach trzciny i także około $2 \%$, w otworach utworzonych w glinianych blokach. Jeżeli już doszło do zasiedlania przestrzeni przez żąłówki, to w około $80 \%$ przypadków komory lęgowe były ukończone w całości (ostatnia przegroda znajdowała się $\mathrm{u}$ wlotu do niszy $\mathrm{w}$ hotelu) dla analizowanych 27 hoteli w Polsce (SiEmaszko 2016).

\section{LOKALIZACJA I MONTAŻ HOTELI}

Głównym problemem w zakresie prawidłowej instalacji hoteli jest znikoma wiedza na temat wpływu takich konstrukcji na biocenologię terenu, w którym maja zostać zainstalowane. Dotychczasowy stan wiedzy jest niewspółmiernie niższy, w stosunku do ha- seł powszechnie używanych przez inicjatorów instalacji hoteli. Takie hasła wydaja się być jedynie opisem idei, nie zaś stanu rzeczywistego, ich treść można sprowadzić do zapewnień dotyczących poprawy i zwiększenia bioróżnorodności w miastach w efekcie zawieszania konstrukcji. Paradoksalnie, ustawianie hoteli dla owadów w przestrzeni miejskiej może doprowadzić do skrócenia czasu kwitnienia gatunków roślin ozdobnych, gdyż wiele roślin zaraz po zapylaniu przestaje inwestować w wystawę kwiatowa $\mathrm{i}$ w ten sposób skraca tę fazę cyklu rozwojowego, która jest najbardziej pożądana $z$ punktu widzenia estetycznego dla ogrodników i lokalnej ludności odwiedzającej tereny zielone w celach rekreacyjnych (WILLMER 2011). Obecne trendy dyktuja montowanie takich obiektów w rejonach występowania zieleni miejskiej. W takich rejonach, przynajmniej teoretycznie, przestrzeń miejska jest bardziej przyjazna od obszarów zwartej zabudowy. Tereny zielone w obrębie miast dostarczaja najwięcej pokarmu w postaci kwitnacych roślin (zdrewniałych i zielnych), których pyłkiem i nektarem odżywiaja się owady. Ponadto, miejskie enklawy dostarczaja wody i schronienia dla bezkręgowców (BANASZAK-CIBICKA i ŻMIHORSKI 2012).

$Z$ racji stosunkowo niewielkiego areału miejsca te stanowia rodzaj regionalnych tzw. hotspotów, w których dochodzi do intensywnego migrowania owadów w poszukiwaniu pokarmu, schronienia oraz miejsc i partnerów do kopulacji. Montowane konstrukcje powinny być umieszczane w miejscach osłoniętych od wiatru i zacinajacego deszczu. Dogodnymi do ulokowania obiektów sa rejony zabudowań, ogrody, ustronne miejsca w parkach i na skwerach, otoczone krzewami chroniacymi od podmuchów porywistego wiatru.

Wloty otworów powinny być w miarę możliwości skierowane $\mathrm{w}$ stronę południową lub południowo-zachodnia, aby zwiększyć ilość słońca docierającego do konstrukcji (MACIVOR i PACKER 2015). Energia słoneczna wpływa korzystnie na tempo rozwoju i metabolizm nowego pokolenia owadów. Orientacja otworów w przestrzeni (położenie w pionie i poziomie) nie odgrywa większej roli, np. w zasiedlaniu ich przez żądłówki $z$ grupy murarek. Posadowienie sztucznego miejsca gniazdowego w gruncie jest możliwe, ale ważnym jest, aby zalegający śnieg nie doprowadzał do zawilgocenia i w konsekwencji zagrzybienia konstrukcji. Istnieje możliwość zminimalizowania ryzyka zamoknięcia hoteli, gdy instalowane sa np. na pniach drzew lub na wspornikach (w przypadku obiektów posadowionych $\mathrm{w}$ gruncie). Istotnym aspektem dla skutecznego zasiedlenia sztucznych 
miejsc gniazdowych jest dostęp do gliny dla samic owadów, które moga $z$ niej budować przegrody pomiędzy komorami. Innymi materiałami służącymi do zasklepienia otworów przez samice moga być: liście, wiórki drewniane i różne frakcje piasku (SIEMASZKO 2016). Umocowanie gniazd, w opinii niektórych badaczy, ma podstawowe znaczenie dla sukcesu zasiedlania obiektów przez owady. Inne opinie na ten temat sugerują, że podwieszanie domków pod koronami większych drzew nie jest najlepszym rozwiazaniem. Dzieje się tak, gdyż zacienienie negatywnie wpływa na zasiedlanie obiektów przez pszczoły. Pszczoły samotnice sa ciepłolubne i dlatego niechętnie będa prowadziły aktywność w rejonach cienia i półcienia. Po wtóre, podwieszenie obiektu musi być wykonane w taki sposób, aby konstrukcja była zamocowana w sposób stabilny i nie poddawała się ruchom wywołanym podmuchami powietrza. Takie ruchy moga być niekorzystne dla pszczół i ich potomstwa, zaburzajac rozwój larw i poczwarek. Wstrzas gniazda wywołany mechanicznym uszkodzeniem może obniżyć przeżywalność potomstwa i procent wygryzających się wiosną owadów (BILIŃSKI i TEPER 2004).

Wysokość nad powierzchnia gruntu nie jest najważniejszym czynnikiem dla sukcesu zasiedlania hoteli. Potwierdzaja to badania (MACIVORY i PACKER 2015) sukcesu zasiedlania hoteli zarówno na zielonych dachach budynków, jak i w ogrodach tuż przy powierzchni gruntu. Wracajac do kwestii rozlokowania hoteli w przestrzeni miejskiej, wyniki badań BANASZAK-CIBICKIEJ i ŻMIHORSKIEGO 2012 dowodza, że różnorodność i liczebność pszczołowatych w aglomeracji miejskiej w Poznaniu się zmienia. Ujawniono znaczna zmienność w składzie gatunkowym i liczebności owadów w zależności od odległości miejsca badań od terenów zielonych i obszarów podmiejskich. Tereny zielone w mieście umożliwiały penetrację owadów do jego centrum (BANASZAK-CIBICKA i współaut. 2016).

W ekosystemach miejskich pozytywny wpływ na różnorodność biologiczna maja refugia o charakterze naturalnym (np. lasy miejskie) (ZIEMIAŃSKI i ZYCH 2016), które zasilaja nowymi gatunkami obszary zurbanizowane (KREMEN i współaut. 2007). Można z tego wnioskować, że na mikroklimat miasta wpływa wiele czynników, które przekładaja się na aktywność oraz obecność owadów i każde miasto może zaoferować im inne warunki.

Pierwszym czynnikiem jest obecność lub brak wody, która jest niezbędna do życia wszystkich organizmów żywych (MICHENER 2000). W mieście woda wydaje się nie być czynnikiem limitującym, gdyż jej rezerwu- arami moga być liczne miejsca. Przykładowo sa to zagłębienia $w$ miejscach nieprzepuszczalnych, oczka wodne i fontanny oraz rosa (okresowo występujaca) na roślinach stanowiących zieleń miejska. Paradoksalnie jej nadmierna obfitość wpływa różnie na zasiedlanie wybranych klas materiałów gniazdowych przez owady. Obecność dużej ilości wody w bliskim sassiedztwie hoteli dla owadów wpływa istotnie negatywnie na sukces tworzenia kompartmentów w trzcinie i drewnie przez żądłówki (SIEMASzKo 2016).

Kolejnym ważnym czynnikiem jest istnienie wyspy cieplnej w miastach, gdzie temperatura gruntu w dni słoneczne może być wyższa w stosunku do terenów podmiejskich. Jej korzystny wpływ na populacje owadów potwierdzają wystapienia gatunków $z$ innych regionów geograficznych w entomofaunie terenów zurbanizowanych (HOSTETLER i MCINTYRE 2001). Przykładem takiego zjawiska dla Polski jest notowanie w parkach obecności pszczolinki rudej (Andrena fulva), gatunku $z$ zachodniej Europy, częstsze niż miało to miejsce w pierwszej połowie XX w. w rejonie Poznania (BANASZAK 1995).

Dodatkowo, w badaniach $z$ terenu Polski stwierdzono pozytywną zależność między stopniem zazielenienia terenu $\mathrm{w}$ bliskim sąsiedztwie a liczba zamkniętych otworów w hotelach dla owadów. Z drugiej strony, wystapiła negatywna korelacja pomiędzy wzrostem udziału powierzchni nieprzepuszczalnej (np. zajętej przez chodniki i ulice) i liczba użytkowanych nisz w konstrukcji (SIEMASZKO 2016).

\section{BENEFICJENCI HOTELI DLA OWADÓW}

Hotele dla owadów, dzięki oferowaniu różnorodnych nisz, moga być zasiedlane przez wiele grup bezkręgowców. W oparciu o badania kanadyjskie (MACIVOR i PACKER 2015), sztuczne miejsca gniazdowe sa wybierane na schronienia zarówno przez rodzime, jak i obce geograficznie żądłówki, ze względu na podobny behawior owadów pochodzacych $z$ różnych rejonów świata. Dowodzi to też plastyczności zachowania się zwierzat $\mathrm{w}$ zmiennych warunkach otoczenia. Ma to miejsce zwłaszcza w przypadku siedlisk przekształconych antropogenicznie. Taka, utworzona przez przestrzeń miejska, mozaika siedlisk jest korzystna dla populacji różnych owadów, odpowiadając szerokiemu spektrum ich wymagań (FORTEL i współaut. 2014). W zależności od proporcji występowania gatunków rodzimych i obcych możemy szacować, czy dostarczenie miejsc lęgowych dla owadów wpłynie na rozwój kilku lub jednej $z$ grup i w efekcie doprowadzi, np. do inwazji gatunku obcego geograficznie. Efekt 
zależy od wielu czynników, między innymi od dostępności pokarmu, jego różnorodności i, w stopniu największym, od stanu wyjściowego i kondycji samych owadów. Zasiedlanie hoteli przez różne gatunki ma znaczenie dla ich ochrony. Jest to jeden $z$ pozytywnych aspektów wynikajacych $z$ ustawiania miejsc gniazdowych dla owadów. W świetle wyników przedstawionych przez MACIVOR i PACKER (2015), poza samotnymi pszczołami, hotele zasiedlane sa przez obce geograficznie osy, które dominuja nad pszczołami pod względem liczebności, zajmując niemal $75 \%$ ogólu dostępnych nisz. Ponadto, ich liczebność, jako jedynej grupy, rosła w kolejnych sezonach prowadzonych badań. Pomiędzy pszczołami rodzimymi i introdukowanymi nie stwierdzono istotnych statystycznie różnic w poziomie zasiedlenia otworów pomiędzy i w trakcie kolejnych sezonów. Dodatkowo sprawdzono, czy lokalizacja hoteli w przestrzeni miejskiej wpływa na ich zasiedlenie. Największy udział $\mathrm{w}$ hotelach ustawionych $\mathrm{w}$ ogrodach prywatnych miały rodzime pszczoły samotne, w ogrodach dachowych natomiast najliczniejsze były obce geograficznie pszczoły. Rodzime osy były najliczniejszymi owadami w parkach miejskich, w odróżnieniu od os obcych (introdukowanych).

W klimacie umiarkowanym dominuje u żądłówek jednoroczny cykl życiowy. Rozpoczyna się wylotem nowego pokolenia wiosna, a kończy w tym samym roku złożeniem jaj latem lub wczesna jesienią. Osobniki, które wykluły się $z$ poczwarek $z$ poczatkiem sezonu, rozpoczynaja loty furażowe trwajace często tylko kilka tygodni. Loty te niejednokrotnie poprzedzone sa kopulacja. Część gatunków to taksony filopatryczne. Ich behawior determinuje powrót do miejsca pierwotnego wylotu $\mathrm{w}$ okresie poszukiwania miejsca na zdeponowanie jaj. Jest to szczególnie częste u bezkręgowców zamieszkujących drewno i glebę (WILLMER 2011). Istnieja odstępstwa od wczesnego zasiedlania hoteli. Przykładem sa smuklikowate (Halictinae), które zasiedlaja miejsca gniazdowe późno. Ich młode nawet na jesieni wylatuja w poszukiwaniu nowych gniazd lub żeruja wokół miejsca wyklucia, które ponownie zasiedlaja (Michener 2000).

Główna grupa zamieszkująca hotele dla owadów są pszczoły. Ich klasyfikacja taksonomiczna nie może się jednak sprowadzić tylko do waskiej frakcji reprezentowanej przez rodzaj Apis. Bardziej odpowiednie jest tu zaklasyfikowanie ogółu tych owadów do nadrodziny Apoidea. Jedynie mniejszość pszczół to gatunki eusocjalne, czyli takie, które tworza kolonie, większość zaś to gatunki żyjące w pojedynkę. Jednak pośród pszczół samotnych występuja również gatun- ki parasocjalne: quasisocjalne i semisocjalne, np. smuklikowate (Halictidae). Przyjmuja one różne formy życia socjalnego, które prowadza do redukcji pasożytnictwa w obrębie grupy gniazd. Dzieje się tak dzięki dzieleniu gniazd między samice, co skutkuje szybszym zamykaniem otworów wlotowych. Inna forma współpracy jest wzajemne wsparcie samic w dostarczaniu pożywienia dla potomstwa. W obrębie grupy samic występuje także podział na zdolne i niezdolne do reprodukcji dla dobra nowego pokolenia.

Pomiędzy taksonami owadów istnieja preferencje w zakresie zakładania gniazd. Przykładowo Xylocopa i Ceratina gniazduja głównie $\mathrm{w}$ drewnie (WILlMER 2011). Natomiast trzcina chętnie zasiedlana jest przez przedstawicieli Megachile (głównie murarkę ogrodowa). Murarka ogrodowa jest gatunkiem związanym historycznie ze starym sposobem budownictwa, polegajacym na kryciu trzciną dachów budynków. Ten materiał został wyparty przez inne pokrycia dachowe $\mathrm{i}$ w niewielkim stopniu jest użytkowany współcześnie, co wpływa na wyraźna utratę tego typu nisz (WóJTOWSKI i współaut. 1995).

Glina zaś pożądana jest przez szerokie spektrum owadów, ale ta występująca w przestrzeni miejskiej jedynie w nikłym stopniu jest wykorzystywana przez owady. Jest to najpewniej warunkowane konkurencja pomiędzy oferowanymi niszami w hotelach i otoczeniu. Jak wykazał ForTEL i współaut. (2014), rodzaj gleby dostępnej dla owadów nie wpływa istotnie na zasiedlenie przez pszczoły samotnice. Gliniane mury i ściany chętnie zasiedlaja m. in. Habropoda, Amegilla, Eucera, Anthophora, Osmia i Megachile (BANASZAK 1993, MichENER 2000). Przykładem gatunku, który znacząco zmniejszył swoja liczebność w wyniku spadku udziału ścian wykonanych $z$ gliny, jest porobnica murarka (Anthophora plagiata), której liczebność drastycznie spadła w ciagu ostanich 30 lat (BANASZAK-CIBICKA i WILKANIEC 2006).

Istnieje ryzyko, że część spośród budowanych przez pszczoły samotne gniazd zostanie zaatakowanych przez pasożyty. Ryzyko jest zwielokrotnione $\mathrm{w}$ przypadku zasiedlania sztucznych hodowli, takich jak hotele dla owadów. Powodem jest to, że liczba potencjalnych gospodarzy dla pasożytów jest bardzo duża i w jednostce czasu może dojść do zainfekowania wielu gniazd sasiadujacych ze soba. Jest to o tyle istotne, że hotele dla owadów moga być odpowiednikami monokultur w rolnictwie lub leśnictwie, w których szkodniki (np. pasożyty) namnażają się bardzo szybko i intensywnie. Przykładami moga być przedstawiciele rodzin takich jak: Megachilide, Drosophilidae (muchówki), Chrysididae (osy pasożytnicze). Sa one chemicznie 
wabione do gniazd żywicieli, gdzie np. deponuja swoje jaja do niezasklepionych kompartmentów. Larwy tych pasożytów wylęgaja się wcześniej niż larwy pszczół samotnic i wyjadaja przeznaczony dla nich pokarm, w efekcie prowadząc do ich śmierci. W przypadku pasożytów $z$ rodzaju Chrysis, larwy złotolitki wykluwają się wcześniej i zjadaja larwy gospodarza (YAMADA 1987, BANASZAK i ROMASENKO 1998, ULBRICH i SIDELMAN 2001). Zwiększone ryzyko pasożytnictwa w przypadku hoteli dla owadów jest największa wada takich konstrukcji. Najwyższy stopień porażenia komórek gniazdowych miał miejsce w przypadku rodzimych pszczół, w stosunku do pszczół samotnych obcych geograficznie, zaś w przypadku os nie stwierdzono istotnych różnic (MACIVOR i PACKER 2015). Z drugiej strony, paradoksalnie, obecność niewielkiej liczby pasożytów gniazdowych stanowi dobry wskaźnik „zdrowia” badanych ekosystemów (FORTEL i współaut. 2014), ponieważ świadczy o dużej różnorodności biologicznej analizowanego terenu.

\section{AKCJE I INICJATYWY LUDZI NA RZECZ OCHRONY OWADOW ZAPYLAJACYCH I KONTEKST PSYCHOSPOŁECZNY}

Od kilkudziesięciu lat ochrona pszczół, poza formą bierna, której przejawem było wydzielanie użytków ekologicznych oraz wzrost liczby rezerwatów, zyskała także charakter czynny. Czynna ochrona przybiera różnorodne formy, a jej zasięg jest zmienny, gdyż te działania maja swoje źródła na różnych szczeblach administracji oraz reprezentuja często oddolne inicjatywy organizacji pozarzadowych i projekty obywatelskie. Wzrost zainteresowania takimi akcjami wiaże się $z$ towarzyszaca im niejednokrotnie promocja medialna (często $\mathrm{w}$ formie ciekawostek) oraz, co nieuniknione, kontrowersjami, jakie wywołuja w wyniku rozmaitego odbioru społecznego. Przychylność części mieszkańców miast w Europie (w tym także w Polsce) skutkuje też pojawieniem się zjawiska „pszczelnictwa miejskiego”, skierowanego na zakładanie uli w obrębie miasta, np. na dachach budynków, czego niegdyś nie brano pod uwagę. Umożliwiła to także zmiana przepisów samorządowych, które niegdyśs postrzegały pszczołę miodna jako zagrożenie dla zdrowia i życia mieszkańców miast i zakazywały tworzenia pasiek $\mathrm{w}$ bezpośredniej bliskości zabudowań. Co więcej, nawet w świadomości laików w dziedzinie entomologii, żądłówki maja (podobnie jak np. motyle) status inny niż ogromna rzesza owadów nazywanych potocznie „robakami”. Jest to zapewne wyrazem zrozumienia ich roli w ekosystemie, wiąże się też $z$ towarzyszacymi im uczuciami. $Z$ jednej strony, żądłówki niewątpliwie docenia się za ich pracę na rzecz zapylania, zaś $z$ drugiej, niekiedy deterministycznie kojarzy $z$ ogromnym zagrożeniem dla zdrowia i życia wynikającym $z$ ryzyka użądlenia (w tym wynikających $z$ niego reperkusji po wstrząsie anafilaktycznym). W oparciu o pozytywne reakcje ludzi niektóre firmy, fundacje i osoby prywatne zainicjowały projekty pod hasłami: „Adoptuj pszczołe”, „Przychylmy pszczołom nieba” czy „Domki dla skrzydlatych, pasiastych przyjaciól" (SIEMASZKO 2016). Ich celem, poza faktyczna ochrona owadów, było poszerzenie wiedzy o przyrodzie i mechanizmach nią rządzacych w kontekście wszechobecnego wplywu człowieka na środowisko. Dlatego też postulowane projekty znalazły przychylność u części społeczeństwa, w tym także u przyrodników. Na pozór godne pochwały, niosa ze soba jednak pewne watpliwości. Przyczyna watpliwości jest znikoma wiedza na temat sytuacji pszczół samotnic, którym dedykowane sa akcje polegajace na tworzeniu sztucznych miejsc gniazdowania owadów. Sa one odpowiednikami powszechnych w parkach miejskich budek lęgowych dla ptaków, nietoperzy i małych ssaków, takich jak jeże i wiewiórki. Odbiór społeczny tego typu inicjatyw rodzi wiele sprzecznych emocji: od głosów pochwały, przez obojetność, po przesadna krytykę, wynikajacca, jak się może wydawać, $z$ niezrozumienia celu inicjatorów i stereotypowego, nieuzasadnionego lęku przed żądłówkami. Objawem negatywnej reakcji społecznej, będacej aktem wandalizmu, jest sprawa hotelu dla owadów w Forcie Bema w Warszawie. Hotel został zniszczony w czerwcu 2015 r., następnie odbudowany 18 lipca i spalony trzy dni później ponownie. Ostatecznie odbudowany w innym miejscu tego parku przetrwał, lecz w opinii spacerowiczów jego estetyka była nieodpowiednia i zamiast wzbogacać park wizualnie, jedynie szpecił swoja formą (SIEMASZKo 2016). Wobec powyższego, jedna $z$ możliwości ustawiania hoteli dla owadów byłoby tworzenie specjalnych, wygrodzonych, niewielkich nieużytków, o podłożu dogodnym do zakładania gniazd przez pszczoły samotnice.

Nie zważając na krytykę, liczba instalowanych tego typu konstrukcji w Polsce rośnie. Możliwe, że przyczyna tego zjawiska jest panująca obecnie moda na tego typu inicjatywy, ale wydaje się, że jest jeszcze zbyt wcześnie, aby rzeczowo na to pytanie odpowiedzieć. Niewątpliwie w ogólnym rozrachunku, niezależnie od sukcesu liczonego $\mathrm{w}$ postaci liczby zasiedlonych otworów przez owady, sztuczne miejsca lęgowe dla owadów spełnily funkcję edukacyjna dla lokalnych społeczności. Co więcej, jednym z 
nowych trendów proponowanych w Skandynawii w celu ochrony zapylaczy było stworzenie koncepcji „pszczelej autostrady” w Oslo, w ramach inicjatywy dotyczacej ochrony różnorodności biologicznej, będacej forma równoległego działania na rzecz ochrony entomofauny terenów zurbanizowanych. Analizujac całe zagadnienie istnienia owadów w miastach, ważna jest także polityka informacyjna i sposób jej prowadzenia. Od ankietowanych uzyskano informacje, że czerpia oni wiedzę zarówno $z$ portali społecznościowych, jak i z innych źródeł, takich jak np. tabliczki informacyjne, będace integralną częścia opisowa do proponowanych konstrukcji. Według ankiet najlepiej poznane przez respondentów były obiekty zlokalizowane najbliżej ich miejsca zamieszkania. Budujący zdaje się być fakt, że ochrona owadów w miastach jest istotna dla ponad $70 \%$ osób ankietowanych. Ponadto ankietowani informowali, że inne formy przyjazne owadom, takie jak laki kwietne lub obszary, które nie podlegaja koszeniu, nie budza sprzeciwu mieszkańców miast. Ankietowani odnajdywali ponadto pozytywny zwiazek między sposobem gospodarowania zielenia a ochrona owadów zapylających, lecz oczekiwali dalszych badan na ten temat. W opinii pytanych, ochrona zapylaczy powinni zajmować się włodarze miast, organizacje pozarzadowe, naukowcy, aktywiści, ogół mieszkańców (SiemaszKo 2016). W postrzeganiu ogrodów przez ludzi również nastapily pewne zmiany zwiazane $z$ hotelami dla owadów. Otóż, pojawił się trend do zakładania tzw. „ogrodów dla pszczół”, w których celowo stosuje się mieszanki nasion gatunków roślin zielnych oraz nasadzenia cebul i sadzonek pożądanych przez pszczoły. Ponadto, takie praktyki stosowane sa też w mikroskali $\mathrm{w}$ postaci prowadzenia upraw w skrzynkach na balkonach budynków (SzEFER 2012). Równolegle obserwuje się wzrost atrakcyjności ogrodów dla owadów, połaczony $z$ poprawa estetyki przestrzeni oraz wzrostem plonów warzyw i owoców w małych sadach i szklarniach (WóJTOWSKI 1979).

Podsumowujac, stawianie hoteli dla owadów ma swoje zalety i wady. Nie jest sposobem na przezwyciężenie zjawiska kryzysu zapyleń na świecie, ale może być znakomitym wstępem do lokalnej poprawy warunków istnienia owadów zapylających. Należy dalej prowadzić liczne wnikliwe badania, aby głębiej zrozumieć opisane zagadnienie i ostatecznie zweryfikować zasadność ustawiania tego typu konstrukcji.

\section{PODZIEKOWANIA}

Chcielibyśmy uprzejmie podziękować dr. Maciejowi Wódkiewiczowi z Zakładu Ekologii Roślin i Ochrony Środowiska Wydziału Bio- logii Uniwersytetu Warszawskiego za korektę oraz cenne uwagi.

\section{Streszczenie}

Owady zapylające podlegaja silnej antropopresji. Zawłaszcza przestrzeń miejska silnie wpływa na zapylacze. Dlatego chcemy zweryfikować zasadność stawiania hoteli dla owadów na terenach miast. Hotele dla owadów sa konstrukcjami składajacymi się $z$ różnych materiałów. Głównie stosowane sa wypełnienia $z$ drewna $z$ otworami, trzciny oraz gliny. Przy czym niezwykle ważna jest jakość wykonania konstrukcji. Wewnątrz tych przestrzeni owady moga przeczekać niekorzystne warunki atmosferyczne, hibernować oraz składać jaja wraz $z$ pokarmem $\mathrm{w}$ celu wyprowadzenia potomstwa. Porównujac dotychczasowe badania należy stwierdzić, że zasadność wznoszenia hoteli dla owadów jest uwarunkowana wieloma czynnikami i jest rozbieżna dla różnych grup owadów. Generalnie stwierdzono, że hotele dla owadów odgrywaja pewna rolę $\mathrm{w}$ istnieniu ich populacji $\mathrm{w}$ miastach. Ponadto instalowanie hoteli dla owadów w miastach wpływa pozytywnie na świadomość społeczna mieszkańców, edukację dzieci i dorosłych $\mathrm{w}$ zakresie biologii zapylania oraz roli owadów w ekosystemach. Jednakże obecnie posiadamy niewiele informacji na temat tego zagadnienia, dlatego istnieje konieczność prowadzenia dalszych badań w tym zakresie.

\section{LITERATURA}

Aizen M. A., L., GaletTo L., 2002. Reproductive success in fragmented habitats: do compatibility systems and pollination specialization matter? J. Veget. Sci. 13, 885-892.

BANASZAK J., 1993. Ekologia pszczót. Wydawnictwo naukowe PWN, Warszawa.

BANASZAK J., 1995. Changes in fauna of wild bees in Europe. Pedagogical University, Bydgoszcz.

BANASZAK J., ROMASENKO L., 1998. Megachilid bees of Europe (Hymenoptera, Apoidea, Megachilidae). Pedagogical University, Bydgoszcz.

BANASZAK-CIBICKA W., 2015. Pszczoły $w$ mieście. Przegląd Komunalny 7, 48-49.

BANASZAK-CIBICKA W., WILKANIEC Z., 2006. PsZczoła porobnica murarka Anthophora plagiata (Illiger, 1806) - ginacy gatunek $w$ Polsce? Chrońmy Przyrode Ojczysta 62, 3-10.

BANASZAK-CIBICKA W., ŻMIHORSKI M., 2012. Wild bees along an urban gradient: winners and losers. J. Insect Conserv. 16, 331-343.

BANASZAK-CIBICKA W., RATYŃSKA H., DYLEWSKI Ł., 2016. Features of urban green space favourable for large and diverse bee populations (Hymenoptera: Apoidea: Apiformes).Urban Forest. Urban Green. 20, 448-452.

BiesmeiJer J. C., RoberTs S. P. M., ReEmer M., OHLEMÜlleR R., EDWARDS M., PEETERS T., SETTELE J., 2006. Parallel declines in pollinators and insect-pollinated plants in Britain and the Netherlands. Science 313, 351-354.

BILIŃSKI M., TEPER D., 2004. Rearing and utilization of the red mason bee - Osmia rufa $L$. (Hymenoptera, Megachilidae) for orchard pollination. J. Apic. Sci. 48, 69-74.

BritTAin C., Williams N., KREMEN C., Klein A. M., 2013. Synergistic effects of non-Apis bees and honey bees for pollination services. Proc. Royal Soc. London B, Biol. Sci. DOI: 10.1098/ rspb.2012.2767. 
Cheptou P. O., Avendaño V. L. G., 2006. Pollination processes and the Allee effect in highly fragmented populations: consequences for the mating system in urban environments. New Phytol. 172, 774-783.

Evans J. D., SAEgerman C., Mullin C., HaubruGE E., NGUYen B. K., FRAZIER M., TARPY D. R., 2009. Colony collapse disorder: a descriptive study. PloS One 4, e6481.

FORTEl L., HENRY M., GUilbaud L., GuiraO A. L., KuHlmanN M., Mouret H., VAISSIËRE B. E., 2014. Decreasing abundance, increasing diversity and changing structure of the wild bee community (Hymenoptera: Anthophila) along an urbanization gradient. PloS One 9 e104679.

GodDARD M. A., Dougill A. J., Benton T. G., 2010. Scaling up form gardens: biodiversity conservation in urban enviorments. Trends Ecol. Evol. 25, 90-98.

Grimm N. B., FAeth S. H., Golubiewski N. E., REDMAN C. L., WU J., BAI X., BRIGGS J. M., 2008. Global change and the ecology of cities. Science 319, 756-760.

HERNANDEZ J. L., FrankIE G. W., THORP R. W., 2009. Ecology of urban bees: a review of current knowledge and directions for future study. Cities Environ. 2, 3.

Hostetler N. E., MCINTYRe M. E., 2001. Effects of urban land use on pollinator (Hymenoptera: Apoidea) communities in a desert metropolis. Basic Appl. Ecol. 2, 209-218.

JEDRZEJEWSKA-SZMEK K., ZYCH M., 2013. Flower-visitor and pollen transport networks in a large city: structure and properties. Arthropod-Plant Interact. 7, 503-516

KAY K. M., Voelckel C., YANG J. Y., HufFord K. M., KASKA D. D., HodGes S. A., 2006. Floral characters and species diversification. [W:] Ecology and evolution of flowers. HARDER L. D., BARRETT S. C. (red.). Oxford University Press on Demand, 311-325.

Knight T. M., Steets J. A., Vamosi J. C., Mazer S. J., BuRd M., CAMPBEll D. R., Dudash M. F., Johnston M. O., Mitchell R. J., Ashman T. L., 2005. Pollen limitation of plant reproduction: pattern and process. Ann. Rev. Ecol. Evol. Systemat. 36, 467-497.

Kremen C., Williams N. M., Aizen M. A., GemMILl-HeRREN B., LeBuhN G., Minckley R., WINFREE R., 2007. Pollination and other ecosystem services produced by mobile organisms: a conceptual framework for the effects of land $\square$ use change. Ecol. Lett. 10, 299-314.

MACIVOR J. S., PACKER, L., 2015. 'Bee hotels' as tools for native pollinator conservation: a premature verdict? PloS One 10, e0122126.

MAKINO T. T., OHASHI K., SAKAI S., 2007. How do floral display size and the density of surrounding flowers influence the likelihood of bumble bee revisitation to a plant? Funct. Ecol. 21, 87-95.

MichenER C. D., 2000. The bees of the world. JHU Press.

Ollerton J., Winfree R., TARRANT S., 2011. How many flowering plants are pollinated by animals? Oikos 120, 321-326.
Potts S. G., BiesmeiJer J. C., Kreme C., NeUMANN, P., SCHWEIGER O., KUNIN W. E., 2010. Global pollinator declines: trends, impacts and drivers. Trends Ecol. Evol. 25, 345-353.

Renner S. S., NEwBery D. M., PRins H. H. T., BROWN N. D., 1998. Effects of habitat fragmentation on plant pollinator interactions in the tropics. [W:] Dynamics of tropical communities. NewBERY D. M., PRINS H. H. T., BROWN N. D. (red.). London: Blackwell Scientific, Oxford, 339-360.

SEnAPATHI D., Goddard M. A., Kunin W. E., BALDOCK K. C., 2016. Landscape impacts on pollinator communities in temperate systems: evidence and knowledge gaps. Funct. Ecol. DOI: $10.1111 / 1365-2435.12809$.

SIEMASZKO M., 2016. Sztuczne miejsca legowe dla zapylaczy („hotele dla pszczót”) w wybranych miastach Polski: kwestia biologii czy komunikacji spolecznej? Archiwum Prac Dyplomowych Uniwersytetu Warszawskiego.

StefFan-Dewenter I., Klein A. M., Gaebele V., AlfERT T., TsCHARNTKE T., 2006. Bee diversity and plant-pollinator interactions in fragmented landscapes. [W:] Plant-pollinator interactions. From specialization to generalization. WASER N. M., Ollerton J. (red.). The University of Chicago Press Books, 387-410.

SzEFER P., 2012. Budowa pułapek gniazdowych dla murarki ogrodowej Osmia rufa L. http:// podlaskie.ksow.pl/publikacje/publikacje-2012. html.

TAKI H., Kevan P. G., 2007. Does habitat loss affect the communities of plants and insects equally in plant-pollinator interactions? Prelim. Find. Biodiver. Conserv. 16, 3147-3161.

UlbRich K., SeIDElmanN K., 2001. Modeling population dynamics of solitary bees in relation to habitat quality. Web Ecol. 2, 57-64.

Williams G. R., TARPY D. R., VANENGELSDORP D., Chauzat M. P., Cox-Foster D. L., Delaplane K. S., ShuTler D., 2010. Colony collapse disorder in context. Bioessays 32, 845-846.

Willmer P., 2011. Pollination and floral ecology. Princeton University Press, Princeton and Oxford.

WóJTOWSKI F., 1979. Spostrzeżenia nad biologia I możliwościami użytkowania pszczoły murarki - Osmia rufa L. (Apoidea: Megachilidae). Roczniki AR w Poznaniu 111, 203-208.

WÓJTOWSKI F., WILKANIEC Z., SZYMAS B., 1995. Increasing the total number of Osmia rufa (L.) (Megachilidae) in selected biotopes by controlled introduction method. [W:] Changes in the fauna of wild bees in Europe. BANASZAK J. (red.). Pedagogical University, 177-180.

YAMADA Y., 1987. Factors determining the rate of parasitism by a parasitoid with a low fecundity, Chrysis shanghaiensis (Hymenoptera: Chrysididae). J. Animal Ecol. 56, 1029-1042.

ZIEMIAŃSKI M. A., ZYCH M., 2016. Pollination biology of the urban populations of an ancient forest, spring ephemeral plant. Acta Soc. Botan. 
KOSMOS Vol. 67, 2, 287-298, 2018

\section{MACIEJ ZiemiańSKI ${ }^{1,2}$, AgATA KLIMCZAK ${ }^{3}$}

${ }^{1}$ Białowieża Geobotanical Station, Faculty of Biology, University of Warsaw, 19 Sportowa Str., 17-230 Białowieża, ${ }^{2}$ Department of Plant Ecology and Environmental Conservation, Faculty of Biology, Biological and Chemical Research Centre, University of Warsaw,

101 Żwirki $i$ Wigury Str., 02-089 Warsaw, ${ }^{3}$ First Faculty of Medicine, Medical University of Warsaw, 61 Żwirki $i$ Wigury Str., 02-091Warsaw,E-mail: m.a.ziemianski@biol.uw.edu.pl,klimczak.agatha@gmail.com

\section{„BEE HOTELS“ - GOOD PRACTICE OR GREAT MISTAKE?}

\section{Summary}

Pollinators are subject to strong anthropopression. Especially the urban space strongly affects pollinators. That is why we want to verify the legitimacy of building "hotelss for insects" in urban areas. Hotels for insects are constructed of different materials. Mainly are used such fillings as: wood with holes, cane and clay. The extremely important is quality of these structures. In the holes, insects can wait for unfavorable weather conditions, hibernate and lay eggs together with food in order to get the offspring. Comparing previous research, it is important to note that the legitimacy of hotel construction for insects is sanctioned by many factors and is divergent for different insect groups. In general, hotels for insects play a role in the existence of insect populations in cities. In addition, installation of insect hotels positively influences public awareness of pollinating biology and the role of insects in ecosystems. However, we currently have little information on this issue, so that further research in this area is still needed.

Key words: anthropopression, hotel for insects, pollination, urban ecosystem 